\title{
Cultural Values on Continuous Improvement in Private Schools in Kuwait
}

\author{
Ali Salem Saleh Al-Haimer Al-Merri ${ }^{1} \&$ Hani J. Irtaimeh ${ }^{1}$ \\ ${ }^{1}$ Business \& Finance Dept., World Islamic for science \& Education University, Jordan \\ Correspondence: Ali Salem Saleh Al-Haimer Al-Merr, Business \& Finance Dept., World Islamic for science \& \\ Education University, Jordan. E-mail: ali051@yahoo.com
}

Received: February 26, 2019

Accepted: March 28, 2020

Online Published: April 14, 2020

doi:10.5539/ijbm.v15n5p37

URL: https://doi.org/10.5539/ijbm.v15n5p37

\begin{abstract}
This study aimed to identify the impact of cultural values on continuous improvement in Kuwaiti private schools. The study was applied over a convenient sample amounting 100 administrators.

The study concluded that there is an effect of cultural values on continuous improvement in private schools in Kuwait. The researcher recommends that there is a need to train employees in private schools to practice cultural values that contribute to continuous improvement, In addition to focus on enhancing work spirit within one team between teachers and school personnel, and to focus on enhancing cultural values prevailing in Kuwaiti society among school students.
\end{abstract}

Keywords: cultural values, continuous improvement, planning, implementation, evaluation and investigation, improvement, private schools

\section{Introduction}

Organizations in our modern world need new ways of thinking, standards and new behavior styles that keep up with the ever-changing external and internal environment. When change indicators and development appear, it transfers to challenge because the organization itself or its staff resist such change due to organizational or individual reasons that prevent them to accept the same.

In light of economic, technological, political and other developments that have been imposed on organizations in general the method of change in order to adapt to environment in which they work in order to serve their goals. We find that this change is an integrated system for managing internal and external information by the organization and in a way that contributes to increasing its capabilities and enhancing its competitive position in the future.

Private educational institutions are not different from other organizations in different sectors in facing different environmental fluctuations that are required to follow up to monitor any opportunities that may appear in the targeted markets, and to avoid any threats that may appear by competitors in the education sector.

This leads to foreseeing the future and predicting any changes that may appear and affect education in private educational institutions quality and continuous improvement they need for various elements of educational process. This also requires taking in consideration that there are cultural values and controls that govern work within the school and may play a role that affect the relationship that can arise between strategic awareness and continuous improvement in education sector.

The education sector in the State of Kuwait is considered one of the most important sectors to which the government gives special importance. Article forty of Kuwaiti constitution stipulates the right of every Kuwaiti to education that the state undertakes until the end of the secondary school stage, as schools have varied between public and private schools (the Ministry of Education in the state Kuwait https://www.moe.edu.kw/

The researcher decided to apply this study to private educational institutions in the State of Kuwait, since it is a sector in which the volume of investments has increased dramatically and competition between private educational institutions has increased in a way that highlights the need to conduct a study centered on measuring the impact of cultural values on continuous improvement in private schools in Kuwait

The importance of this study stems of being useful in practical aspect for educational sector in the State of 
Kuwait for private schools in particular that want to compete in the school education market. This study will help them to continue in the targeted market for a long period in the light of using different educational methods and techniques.

As for scientific aspect, the importance of this study highlights the importance of the topic, which aims to identify the impact of cultural values on continuous improvement in private schools in Kuwait, where no other studies, according to the researcher's knowledge, have conducted such kind of studies, which contributes to adding a scientific effort The Arab Scientific Library

\subsection{Problem Statement}

The study problem emerges that cultural values were not previously linked with continuous improvement in private educational institutions, which makes it is important to carry out such study to benefit from in improving the education quality in Kuwait schools. The study problem can be summarized in answering the following questions:

- What is the level of continuous improvement in educational institutions of the State of Kuwait?

- What are the cultural values in the educational institutions of the State of Kuwait?

- What is the effect of cultural values on continuous improvement in private schools in Kuwait?

\section{Hypotheses Testing}

\subsection{Main Hypothesis}

H01: There is no impact of cultural values on continuous improvement in private schools in Kuwait

H01.1: There is no impact of cultural values on planning as an element of continuous improvement in private schools in Kuwait

H01.2: There is no impact of cultural values on implementation as an element of continuous improvement in private schools in Kuwait

H01.3: There is no impact of cultural values on appraisal and investigation as an element of continuous improvement in private schools in Kuwait

H01.4: There is no impact of cultural values on improvement as an element of continuous improvement in private schools in Kuwait

\section{Theoretical Framework}

\subsection{Continuous Improvement}

Organizations face significant competition in the targeted markets regardless the sector in which they operate, and this requires to continuously improving performance, not only manufacturing performance but also financial performance and improving services as well. Continuous Improvement (CI) will help in assuring the quality, customer satisfaction, reduce cost and increase efficiency, and the impact of continuous improvement will positively affect the performance of the organization and without it is difficult for them to stay competitive.

The roots of continuous improvement called the Kaizen term started by Japanese, as its meaning in Japanese is (Kai): it means good change and (Zen) means the best, as it relies on scientific method to control quality and adapt to values and beliefs and Organizational traditions focused on employee retention (David, David, and Khalil, 2015). Deming (2012) has defined continuous improvement as "the organization's broad focus for better process performance". Choo, Linderman and Schroeder (2007) defined it as a "gradual improvement towards innovation."

And because continuous improvement aims to eliminate non-value-added activities, waste or losses, it will be a reason to produce the product properly from the first attempt. Locher (2011) Continuous improvement can be achieved through the following:

- $\quad$ Reducing defect or damage rates

- $\quad$ Reduced response time

- Increased delivery obligations

- Product, service and operation evaluation

- Involving customers in the product

- Increase productivity 
- Improving quality performance

- Improving employee commitment to work

- $\quad$ Cost Reduction (2018, Khan, Sikandar \& Hongqi)

The current study will adopt the following steps for continuous improvement, extracted from Kaizen model and Deming PDCA cycle for: (David et al., 2015), (Al-Enezi, 2009) and (Saleh, 2017.)

- Planning ( Plan ): where the current situation of organization is studied and the plan is put in place to meet any existing problems in a manner that match with planed goals

- Implementation (Do): where the plan for development and improvement is implemented, and monitoring its progress and collecting the various data accompanying it

- Assessment and Check: The collected data is processed and verified to what extent the organization is close to achieving its set goals.

- Improvement (ACT): In the event that the plan in place succeeded in achieving its objectives, at this stage this defect will be approved in the future. As for the imbalance that continues, the administration will correct it and address it until the set goals are achieved.

\subsection{Cultural Values}

Culture is the most effective environmental factor in individual behavior and is determined by values and beliefs in the society. Culture can be defined as the complex set of knowledge, faith, art, law, ethics, customs, and any other abilities and norms that humans acquire as members of society (Hawkins, Mothersbaugh, 2010,42).

Hofstede (2001) defines culture as shared values that distinguish group from another.Cultural values are defined as "lasting beliefs that a particular mode of behavior is favored by individuals or society and it is necessary not to violate it" (Chegini, Molan \& Kashanifar, 2016)

Cultural values represent "abstract, implicit or explicit ideas about what are good, right, and desirable in society" (Phuong \& Harima, 2019) and act as guidance for individual values. Moreover, it should be noted that cultural values "are not related to the region but are widely adhered to and remain intact despite pressure from the unit or group" (Morris \& Schindehutte, 2005, 454).

The characteristics of cultural values can be summarized as follows:

- The cultural values of other societies can be learned in three ways: formal learning, informal learning and technical learning.

- Cultural values guide individual's behavior by setting cultural roles

- Cultural values are permanent as well as dynamic.

- Cultural values are prevalent, and common values that distinguish one culture from another (Chegini, et al, 2016).

Cultural values can be divided into internal values (self-esteem, a sense of accomplishment, self-realization), personal relationships or enjoyment (enjoyment, excitement)), and other external (warm relationships with others, being respected, a sense of belonging, security). (Watkins and G noth, 2005, 227).

\section{Study Population and Sampling}

The study population consists of administrators in private educational institutions in the State of Kuwait. The researcher draw convenient sample consisted of 100 administrators to distribute the study questionnaire, all questionnaires were collected.

\subsection{Validity and Reliability}

The researcher displayed the study instrument (the questionnaire) to a panel of Jordanian universities and Kuwaiti universities, in order to express an opinion regarding questionnaire paragraphs number and the extent of clarity, and coherence.

As for study tool reliability, the researcher used Cronbach Alpha coefficient in order to verify study tool reliability. Questionnaire Alpha value was 0.744 , which is an excellent ratio, being higher than the acceptable percentage 0.60 (Sekaran \& Bougie, 2010)

\subsection{Research Methodology}

The researcher used the descriptive analytical method. Periodicals, books and electronic articles were used for 
the theoretical framework. Field work was made by designing the questionnaire to serve study objectives.

\subsection{Data collection Source}

\subsubsection{Primary Data}

It consists of the questionnaire. It is based on questions related to the study variables, which must be understood and related to study objectives

\subsubsection{Secondary Data}

It includes the literature review and previous studies that handled the study subject and its variables.

\subsubsection{Descriptive Statistics}

Means and standard deviations were calculated to describe the sample responses

Table 1. Means and standard deviations of sample's responses regarding cultural values

\begin{tabular}{|c|c|c|c|}
\hline No. & Statements & Mean & $\begin{array}{l}\text { Standard } \\
\text { Deviation }\end{array}$ \\
\hline 1 & Distinguished students are respected at school & 4.16 & .395 \\
\hline 2 & .Emphasis is placed on ethics of educational work in the school & 4.22 & .416 \\
\hline 3 & The school administration focuses on ethical interaction among students & 4.30 & .503 \\
\hline 4 & $\begin{array}{l}\text { Collaboration with parents is carried out to improve student performance in } \\
\text { school }\end{array}$ & 4.49 & .541 \\
\hline 5 & $\begin{array}{l}\text { Any problems in the school are addressed immediately so that things do not } \\
\text { get worse }\end{array}$ & 4.33 & .514 \\
\hline 6 & $\begin{array}{l}\text { There is an interest in promoting the principle of reward and punishment for } \\
\text { school students. }\end{array}$ & 4.33 & .493 \\
\hline 7 & $\begin{array}{l}\text { The concept of belonging to a school for students and teachers is } \\
\text { strengthened }\end{array}$ & 4.16 & .526 \\
\hline 8 & $\begin{array}{l}\text { There is an interest in obtaining the opinions of parents and students about } \\
\text { the quality of the educational service provided to them }\end{array}$ & 4.43 & .573 \\
\hline 9 & $\begin{array}{l}\text { There is a focus on enhancing the spirit of work within one team between } \\
\text { teachers and school staff }\end{array}$ & 4.23 & .468 \\
\hline \multirow[t]{2}{*}{10} & $\begin{array}{l}\text { There is a focus on enhancing cultural values prevailing in Kuwaiti society } \\
\text { among school students }\end{array}$ & 4.33 & .514 \\
\hline & General Mean & 4.2980 & .19068 \\
\hline
\end{tabular}

Table 1 shows means of sample subjects' responses on statements that measure the cultural values. It is found that there are positive attitudes toward above statements because their means are greater than mean of the scale. 
Table 2. Means and standard deviations of sample's responses regarding continuous improvement

\begin{tabular}{|c|c|c|c|}
\hline No. & Statements & Mean & $\begin{array}{l}\text { Standard } \\
\text { Deviation }\end{array}$ \\
\hline 1 & $\begin{array}{l}\text { The school administration develops a strategic plan that contributes to } \\
\text { achieving its goals }\end{array}$ & 4.43 & .537 \\
\hline 2. & Executive mechanisms are placed to satisfy students and their families needs & 4.31 & .486 \\
\hline 3. & $\begin{array}{l}\text { There is an interest in developing plans to develop educational services in } \\
\text { the school }\end{array}$ & 3.99 & .643 \\
\hline 4 & A clear plan is established to manage any crisis the school face & 3.93 & .728 \\
\hline 5 & Emphasis is placed on developing plans to measure their results & 4.20 & .725 \\
\hline 6 & The plans are executed accurately & 4.27 & .446 \\
\hline 7 & $\begin{array}{l}\text { Implementation placed plans } \\
\text { mechanisms are controlled }\end{array}$ & 4.41 & .514 \\
\hline 8 & $\begin{array}{l}\text { Emphasis is placed on terms of each plan implementation in accordance } \\
\text { with the established procedures }\end{array}$ & 4.49 & .541 \\
\hline 9 & $\begin{array}{l}\text { There is an interest in collecting data and information necessary to } \\
\text { implement the plan }\end{array}$ & 4.27 & .468 \\
\hline 10 & $\begin{array}{l}\text { The implementation of the plan is linked to teachers and administrators } \\
\text { rewards }\end{array}$ & 4.28 & .621 \\
\hline 11 & The plan results are carefully evaluated & 4.25 & .435 \\
\hline 12 & $\begin{array}{l}\text { The school administration examines the results of any plan implementation } \\
\text { accurately }\end{array}$ & 4.28 & .451 \\
\hline 13 & A comparison is made between the placed goals and what has been achieved & 4.40 & .532 \\
\hline 14 & The results are scientifically examined & 4.33 & .637 \\
\hline 15 & The data collected is processed to assess the achievement rate of the plan & 4.29 & .456 \\
\hline 16 & $\begin{array}{l}\text { Constant adjustments are made on the mechanisms for implementing the } \\
\text { plan }\end{array}$ & 4.22 & .440 \\
\hline 17 & $\begin{array}{l}\text { Mechanisms are placed to treat any defect that appears as a result of } \\
\text { implementing the plan }\end{array}$ & 4.25 & .539 \\
\hline 18 & $\begin{array}{l}\text { The school administration link assessment and examination results through } \\
\text { plan improvement }\end{array}$ & 4.47 & .577 \\
\hline 19 & $\begin{array}{l}\text { There is a focus on developing mechanisms for implementing future plans } \\
\text { in the school }\end{array}$ & 4.33 & .570 \\
\hline \multirow[t]{2}{*}{20} & $\begin{array}{l}\text { The opinions of all those involved in implementing the plan are taken with a } \\
\text { view to identifying any negative points that affect its implementation. }\end{array}$ & 4.22 & .484 \\
\hline & General Mean & 4.2810 & .20717 \\
\hline
\end{tabular}

Table 3 shows means of sample subjects' responses on statements that measure the continuous improvement. It is found that there are positive attitudes toward above statements because their means are greater than mean of the scale.

\subsection{Hypotheses Testing}

\subsubsection{Main Hypothesis}

H01: There is no impact of cultural values on continuous improvement in private schools in Kuwait 
Table 4. Ho test

\begin{tabular}{lllll}
\hline \multicolumn{4}{c}{ Model Summary } & \\
Model & $\mathrm{R}$ & R Square & Adjusted R Square & $\begin{array}{l}\text { Std. Error of the } \\
\text { Estimate }\end{array}$ \\
\hline 1 & $.596^{\mathrm{a}}$ & .355 & .349 & .16718 \\
\hline
\end{tabular}

\begin{tabular}{|c|c|c|c|c|c|c|}
\hline \multicolumn{7}{|c|}{ ANOVA } \\
\hline Model & & Sum of Squares & $\mathrm{df}$ & Mean Square & $\mathrm{F}$ & Sig. \\
\hline \multirow{3}{*}{1} & Regression & 1.510 & 1 & 1.510 & 54.015 & $.000^{\mathrm{b}}$ \\
\hline & Residual & 2.739 & 98 & .028 & & \\
\hline & Total & 4.249 & 99 & & & \\
\hline \multicolumn{7}{|c|}{ Coefficients } \\
\hline \multirow[t]{2}{*}{ Model } & & \multicolumn{2}{|c|}{ Unstandardized Coefficients } & $\begin{array}{l}\text { Standardized } \\
\text { Coefficients }\end{array}$ & $\mathrm{t}$ & Sig. \\
\hline & & B & Std. Error & Beta & & \\
\hline \multirow{2}{*}{1} & (Constant) & 1.497 & .379 & & 3.950 & .000 \\
\hline & in & .648 & .088 & .596 & 7.349 & .000 \\
\hline
\end{tabular}

Simple regression test was used to test the above hypothesis. The test indicates that $\mathrm{t}$ value is $\mathrm{t}=7.349$ which is statistically significant at 0.05 level. $\mathrm{R}=0.596$ reflects the relationship strength between the independent variable and the dependent variable, therefore it can be concluded that there is an Impact of cultural values on continuous improvement in private schools in Kuwait

The following sub-hypotheses are derived:

H01.1: There is no impact of cultural values on planning as an element of continuous improvement in private schools in Kuwait

Table 5. Ho1 test

\begin{tabular}{lllll}
\hline \multicolumn{4}{c}{ Model Summary } & \\
Model & $\mathrm{R}$ & R Square & Adjusted R Square & $\begin{array}{l}\text { Std. Error of the } \\
\text { Estimate }\end{array}$ \\
\hline 1 & $.348^{\mathrm{a}}$ & .121 & .112 & .38907 \\
\hline
\end{tabular}

\begin{tabular}{|c|c|c|c|c|c|c|}
\hline \multicolumn{7}{|c|}{ ANOVA } \\
\hline Model & & Sum of Squares & $\mathrm{df}$ & Mean Square & $\mathrm{F}$ & Sig. \\
\hline \multirow{3}{*}{1} & Regression & 2.047 & 1 & 2.047 & 13.522 & $.000^{\mathrm{b}}$ \\
\hline & Residual & 14.835 & 98 & .151 & & \\
\hline & Total & 16.882 & 99 & & & \\
\hline \multicolumn{7}{|c|}{ Coefficients } \\
\hline \multirow{2}{*}{ Model } & & \multicolumn{2}{|c|}{ Unstandardized Coefficients } & Standardized & t & $\mathrm{Sig}$ \\
\hline & & $\mathrm{B}$ & Std. Error & Beta & & \\
\hline \multirow{2}{*}{1} & (Constant) & .931 & .882 & & 1.055 & .294 \\
\hline & ind & .754 & .205 & .348 & 3.677 & .000 \\
\hline
\end{tabular}

Simple regression test was used to test the above hypothesis. The test indicates that $\mathrm{t}$ value is $\mathrm{t}=3.677$ which is statistically significant at 0.05 level. $\mathrm{R}=0.348$ reflects the relationship strength between the independent variable and the dependent variable, therefore it can be concluded that there is an impact of cultural values on planning as an element of continuous improvement in private schools in Kuwait

H01.2: There is no impact of cultural values on implementation as an element of continuous improvement in private schools in Kuwait 
Table 6. Ho2 test

\begin{tabular}{lllll}
\hline \multicolumn{4}{c}{ Model Summary } & \\
Model & $\mathrm{R}$ & R Square & Adjusted R Square & $\begin{array}{l}\text { Std. Error of the } \\
\text { Estimate }\end{array}$ \\
\hline 1 & $.370^{\mathrm{a}}$ & .137 & .128 & .22846 \\
\hline
\end{tabular}

\begin{tabular}{lllllll}
\hline \multicolumn{5}{c}{ ANOVA } \\
Model & & Sum of Squares & df & Mean Square & F & Sig. \\
\hline \multirow{3}{*}{1} & Regression & .811 & 1 & .811 & 15.541 & $.000^{\mathrm{b}}$ \\
& Residual & 5.115 & 98 & .052 & & \\
\hline & Total & 5.926 & 99 & & & \\
\hline
\end{tabular}

\begin{tabular}{|c|c|c|c|c|c|c|}
\hline \multicolumn{7}{|c|}{ Coefficients } \\
\hline \multirow{2}{*}{ Model } & & \multicolumn{2}{|c|}{ Unstandardized Coefficients } & \multirow{2}{*}{$\begin{array}{l}\text { Standardized } \\
\text { Coefficients } \\
\text { Beta }\end{array}$} & \multirow{2}{*}{$\mathrm{t}$} & \multirow{2}{*}{ Sig. } \\
\hline & & B & Std. Error & & & \\
\hline \multirow{2}{*}{1} & (Constant) & 2.304 & .518 & & 4.447 & .000 \\
\hline & ind & .475 & .120 & .370 & 3.942 & .000 \\
\hline
\end{tabular}

Simple regression test was used to test the above hypothesis. The test indicates that $t$ value is $t=3.942$ which is statistically significant at 0.05 level. $R=0.370$ reflects the relationship strength between the independent variable and the dependent variable, therefore it can be concluded that there is an impact of cultural values on implementation as an element of continuous improvement in private schools in Kuwait

H01.3: There is no impact of cultural values on appraisal and investigation as an element of continuous improvement in private schools in Kuwait

Table 7. Ho3 test

\begin{tabular}{lllll}
\hline \multicolumn{4}{c}{ Model Summary } & \\
Model & $\mathrm{R}$ & R Square & Adjusted R Square & $\begin{array}{l}\text { Std. Error of the } \\
\text { Estimate }\end{array}$ \\
\hline 1 & $.515^{\mathrm{a}}$ & .266 & .258 & .19491 \\
\hline
\end{tabular}

\begin{tabular}{lllllll}
\hline & & \multicolumn{2}{c}{ ANOVA } & & Sig. \\
\hline \multirow{4}{*}{1} & & Sum of Squares & df & Mean Square & F & $.000^{\mathrm{b}}$ \\
& Regression & 1.347 & 1 & 1.347 & 35.458 & \\
& Residual & 3.723 & 98 & .038 & & \\
\hline
\end{tabular}

\begin{tabular}{|c|c|c|c|c|c|c|}
\hline \multicolumn{7}{|c|}{ Coefficients } \\
\hline \multirow{2}{*}{ Model } & & \multicolumn{2}{|c|}{ Unstandardized Coefficients } & \multirow{2}{*}{$\begin{array}{l}\text { Standardized } \\
\text { Coefficients } \\
\text { Beta }\end{array}$} & \multirow[t]{2}{*}{$\mathrm{t}$} & \multirow{2}{*}{ Sig. } \\
\hline & & B & Std. Error & & & \\
\hline \multirow{2}{*}{1} & (Constant) & 1.681 & .442 & & 3.803 & .000 \\
\hline & Ind & .612 & .103 & .515 & 5.955 & .000 \\
\hline
\end{tabular}

Note. a. Dependent Variable: dep3

Simple regression test was used to test the above hypothesis. The test indicates that $\mathrm{t}$ value is $\mathrm{t}=5.955$ which is statistically significant at 0.05 level. $\mathrm{R}=0.515$ reflects the relationship strength between the independent variable and the dependent variable, therefore it can be concluded that there is an impact of cultural values on appraisal 
and investigation as an element of continuous improvement in private schools in Kuwait

H01.4: There is no impact of cultural values on improvement as an element of continuous improvement in private schools in Kuwait

Table 8. Ho4 test

\begin{tabular}{lllll}
\hline \multicolumn{4}{c}{ Model Summary } & \\
Model & $\mathrm{R}$ & R Square & Adjusted R Square & $\begin{array}{l}\text { Std. Error of the } \\
\text { Estimate }\end{array}$ \\
\hline 1 & $.538^{\mathrm{a}}$ & .289 & .282 & .22531 \\
\hline
\end{tabular}

\begin{tabular}{lllllll}
\hline & & \multicolumn{2}{c}{ ANOVA } \\
Model & & Sum of Squares & df & Mean Square & F & Sig. \\
\hline \multirow{3}{*}{1} & Regression & 2.025 & 1 & 2.025 & 39.882 & $.000^{\mathrm{b}}$ \\
& Residual & 4.975 & 98 & .051 & & \\
& Total & 7.000 & 99 & & & \\
\hline
\end{tabular}

Coefficients

\begin{tabular}{|c|c|c|c|c|c|c|}
\hline \multirow[t]{2}{*}{ Model } & & \multicolumn{2}{|c|}{ Unstandardized Coefficients } & $\begin{array}{l}\text { Standardized } \\
\text { Coefficients }\end{array}$ & \multirow[t]{2}{*}{$-\mathrm{t}$} & \multirow[t]{2}{*}{ Sig. } \\
\hline & & B & Std. Error & Beta & & \\
\hline \multirow{2}{*}{1} & (Constant) & 1.075 & .511 & & 2.103 & .038 \\
\hline & ind & .750 & .119 & .538 & 6.315 & .000 \\
\hline
\end{tabular}

Simple regression test was used to test the above hypothesis. The test indicates that $t$ value is $t=6.315$ which is statistically significant at 0.05 level. $\mathrm{R}=0.538$ reflects the relationship strength between the independent variable and the dependent variable, therefore it can be concluded that there is an impact of cultural values on improvement as an element of continuous improvement in private schools in Kuwait

\section{Conclusions and Recommendations}

This study aimed to identify the impact of cultural values on continuous improvement in private schools in Kuwait. The study was applied to a sample of 100 administrators.

It has been concluded that there is an impact of cultural values on continuous improvement in private schools in Kuwait, as well as an impact of cultural values on planning as an element of continuous improvement in private schools in Kuwait, and there is an impact of cultural values on implementation as an element of continuous improvement in private schools In Kuwait, and there is an impact of cultural values on evaluation and examination as an element of continuous improvement in private schools in Kuwait, and there is an impact of cultural values on improvement as an element of continuous improvement in private schools in Kuwait.

This reflects high level of awareness of cultural values importance in private schools. The most prominent impact on improvement as an element of continuous improvement, which makes it necessary to make several recommendations related to strengthening the concept of cultural values in private schools in Kuwait, since it is necessary to train employees in Private schools in practicing the cultural values that contribute to continuous improvement, in addition to focusing on enhancing the spirit of work within one team between teachers and school employees, and focusing on promoting cultural values prevailing in Kuwaiti society among school students

\section{References}

Al-Anzi, Q. (2009). The possibility of applying the approaches of continuous improvement in university education. A field study in the faculties of Administration and Economics / University of Kufa. Journal of the Center for Kufa Studies, 1(21), 335-358.

Chegini, F., Molan, S., \& Kashanifar, S. (2016). An Examination of the Impact of Cultural Values on Brand Preferences in Tehran's Fashion Market. Procedia Economics and Finance, 36, 189-200. https://doi.org/10.1016/S2212-5671(16)30030-2

Choo, A. S., Linderman, K., \& Schroeder, R. G. (2007). Method and context perspectives on learning and 
knowledge creation in quality management. Journal of Operations Management, 25(4), 918-931. https://doi.org/10.1016/j.jom.2006.08.002

Dawood, G., Dawood, F., \& Khalil, A. (2015). The role of business process re-engineering in continuous improvement. An exploratory study of opinions of a sample of teaching staff in the faculties of Law, Administration and Economics - University of Baghdad. Journal of Accounting and Financial Studies, $10(33), 19-45$.

Deming, W. E. (2012). The new economics: For industry, government, education. Technometrics, 38(3), 294-295. https://doi.org/10.1080/00401706.1996.10484521

Hawkins, D. I., \& Mothersbaugh, D. L. (2010). Consumer behavior: building marketing strategy (11th ed.). McGraw-Hill/Irwin.

Hofstede, G. (2001). Culture's consequence: Comparing values, behaviors, institutions and organizations across nations. Beverly Hills, CA: SAGE.

Khan, H., Sikandar, S., \& Hongqi, L. (2018). Impact of Continuous Improvement on Organization Performance Insight from Pakistan: An Empirical Study. International Journal of Innovation, Management and Technology, 9(1), 7-14. https://doi.org/10.18178/ijimt.2018.9.1.779

Locher, D. (2011). Lean Office and Service Simplified. New York: Productivity Press.

Morris, M., \& Schindehutte, M. (2005). Entrepreneurial values and the ethnic enterprise: An examination of six subcultures. Journal of Small Business Management, 43(4), 453-479. https://doi.org/10.1111/j.1540-627X.2005.00147.x

Phuong, Q., \& Harima, A. (2019). The impact of cultural values on Vietnamese ethnic entrepreneurs in Germany. Journal of Entrepreneurship, Management and Innovation (JEMI), 15(2), 85-115. https://doi.org/10.7341/20191524

Saleh, M. (2017). Elements of continuous improvement and its role in achieving sustainable competitive advantage: an analytical study at (Carrefour). Tikrit Journal of Administrative and Economic Sciences, 2(38), 144-180.

Sekaran, U., \& Bougie, R. (2010). Research methods for business: A skill building approach. John Wiley \& Sons.

Watkins, L., \& Goth, J. (2005). Methodological issues in using Kahle's list of values scale for Japanese tourism behavior. Journal of Vacation Marketing, 11(3), 225-233. https://doi.org/10.1177/1356766705055708

\section{Copyrights}

Copyright for this article is retained by the author(s), with first publication rights granted to the journal.

This is an open-access article distributed under the terms and conditions of the Creative Commons Attribution license (http://creativecommons.org/licenses/by/4.0/). 